\title{
New records of Chironomidae (Diptera: Insecta) from the Azores, Macaronesia
}

\author{
D.A. Murray ${ }^{1}$, S.J. Hughes 2,3 , M.T. Furse ${ }^{4}$, W.A. Murray 1 \\ ${ }^{1}$ Department of Zoology, National University of Ireland, Dublin, Belfield, Dublin 4, Ireland, E-mail : declan.murray@ucd.ie \\ 2 Laboratorio Regional de Engenharia Civil, Dept de Recursos Naturais e de Hidraulica, Rua Agostinho Pereira de Oliveira, $9000-264$ Funchal, \\ Portugal. E-mail : shughes@1rec.pt \\ ${ }^{3}$ Centro de Estudos da Macronesia, Universidade da Madeira, Campus de Penteada, 9000 Funchal, Portugal. \\ ${ }^{4}$ Centre for Ecology and Hydrology, East Stoke, Dorset, BH20 6BB, England. E-mail : mtf@ceh.ac.uk
}

\begin{abstract}
Collections of Chironomidae from aquatic habitats on the Azores islands of São Miguel and Flores during August 1997 and on São Miguel, Terceira and Graciosa in September-October 1998, yielded 33 species-level taxa. Representatives of 16 taxa in three subfamilies are new generic / species records for the Azores archipelago: Tanypodinae - Procladius (Holotanypus) choreus (Meigen), Paramerina sp. griechenland, Zavrelimyia sp.; Orthocladiinae - Metriocnemus (Inermipupa) carmencitabertarum Langton et Cobo, Orthocladius (Eudactylocladius) sp., Psectrocladius limbatellus (Holmgren), Psectrocladius sp., Pseudorthocladius sp., Smittia contingens (Walker); Chironominae - Chironomus cingulatus Meigen, Chironomus cf annularius (De Geer), Glyptotendipes barbipes (Staeger), Glyptotendipes pallens (Meigen), Polypedilum nubifer (Skuse), Micropsectra sp. (cf lindrothi Goetghebuer), Paratanytarsus grimmii (Schneider). A revised checklist is provided, incorporating and updating previous records.
\end{abstract}

Keywords : Insecta, Chironomidae, Azores, Macaronesia, distribution.

\section{Introduction}

The islands of the Azores archipelago lie in the Atlantic Ocean approximately $1,600 \mathrm{~km}$ west of Portugal between latitudes $39^{\circ} 43^{\prime} \mathrm{N}$ and $36^{\circ} 95^{\prime} \mathrm{N}$. The islands are of volcanic origin, have a total landmass area of $2,333 \mathrm{~km}^{2}$ and span a distance of approximately $500 \mathrm{~km}$ in a general north-west sequence between longitudes $25^{\circ} 00^{\prime} \mathrm{W}$ and $31^{\circ} 05^{\prime} \mathrm{W}$. Three groups of islands are recognised, the eastern group of São Miguel, Santa Maria and the Formigas islet, a central group of Faial, Pico, São Jorge, Terceira and Graciosa and the western group of Flores and Corvo (Fig.1). The islands experience a temperate / sub-tropical climate and high humidity resulting from the direct influence of the Gulf Stream. Annual land temperatures range between $14^{\circ} \mathrm{C}$ and $25^{\circ} \mathrm{C}$ while the surrounding seawaters vary between $16^{\circ} \mathrm{C}$ and $22^{\circ} \mathrm{C}$. The flora is predominantly of European and Mediterranean origin.

The Azorean insect fauna has been the subject of many investigations during the last century. Viera \& Borges (1993) and Borges \& Viera (1994) provide a comprehensive bibliography of these entomological studies covering a diverse range of taxonomic groups. More recently Kehlmaier (1998) compiled a database and checklist of the dipteran species previously recorded from the Azores based on all relevant late $19^{\text {th }}$ and $20^{\text {th }}$ century studies. Most information on the Azorean chironomid fauna stems from collections made in 1938 by Frey, Storå and Cedercreutz and reported by Storå (1945). Subsequently, Freeman (1959) examined and reported on collections made by Brinck and Dahl from the Lund University Expedition to Madeira and the Azores in 1957. Kehlmaier (1998), «not claiming completeness or actuality» provided a list of the species-level chironomid taxa compiled from these studies but citations were based on earlier taxonomic concepts and did not take account of recent taxonomic advances or generic revisions. Cobo et al. (2002) applied current taxonomy to the existing Azorean records in their recent inventory of Portuguese Chironomidae. A total of 33 Azorean species-level taxa is recognised in the literature, four of which were deemed nomina dubia by Ashe and Cranston (1990) while Cobo et al. (2002) cite five nomina dubia. In 1997 and 1998 Chironomidae were collected from aquatic habitats on four islands of 


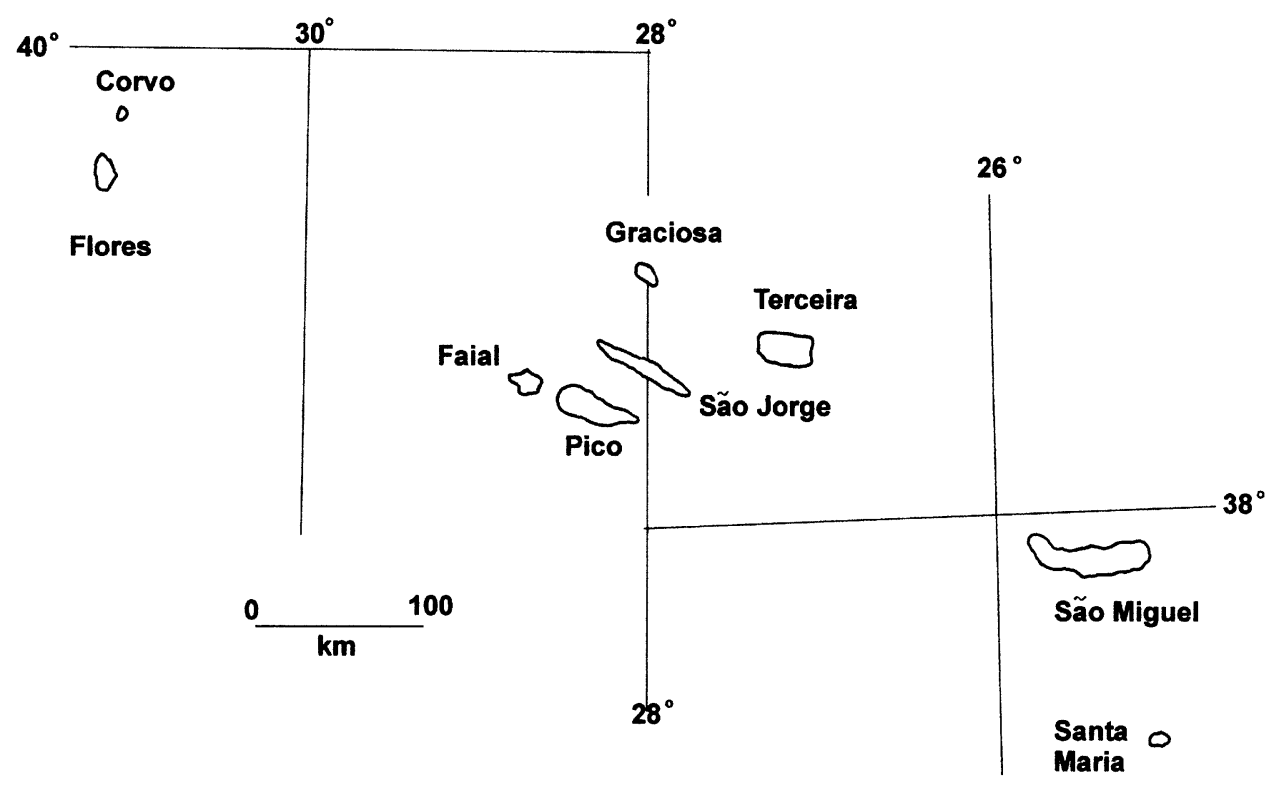

Fig. 1. Islands of the Azores Archipelago.

the Azorean archipelago: São Miguel and Flores (August 1997 - M.T. Furse), São Miguel, Terceira and Graciosa (September/October 1998 - M.T. Furse, S.J. Hughes, D. Murray, W. Murray). The results of these studies, providing new records and clarification of the status of some existing records, are presented in this paper.

\section{Methods}

Adult Chironomidae were collected by aerial sweep netting. Skimming of surface waters of ponds, reservoirs, animal drinking troughs and ornamental ponds and fountains, by fine-mesh net using techniques described by Langton (1991) or by use of drift nets placed in flowing waters, yielded pupal exuviae and some pharate adults. Some collections were made in open deep wells by lowering a drift net to obtain surface floating exuviae. Larvae were obtained at some sites. All specimens were preserved in $70 \%$ alcohol and later processed and treated according to methods outlined in Wiederholm (1983, 1986, 1989 for larvae, pupal exuviae and adults respectively).

Because of the restricted number of exposed natural freshwater habitats on the islands, collection effort in some cases was restricted to artificial habitats such as stone or concrete watering troughs, abandoned baths, and artificial and ornamental pools, which none the less proved to be rich sources of chironomid material. Specimens were obtained in a total of 55 collections, from inland habitats associated with freshwaters and also in some marine coastal areas, on the four islands visited. Seventeen collections ( 2 marine) were undertaken on São Miguel, 20 (4 marine) on Terceira, 15 (3 marine) on Graciosa and 3 on Flores (no marine samples). Details of site locations and dates on which collections were made are given in Table 1.

\section{Results}

\section{The chironomid taxa recorded}

A list of the taxa present in the samples examined from the 55 collections is given in Table 2. Thirtythree species-level taxa from the subfamilies Telmatogetoninae, Tanypodinae, Orthocladiinae and Chironominae were identified, sixteen of which constitute records not cited for the archipelago in previous literature. Determinations by previous workers were based on features of the adult male imago alone whereas modern chironomid systematics relies on characters from all life history stages, pupal exuviae particularly yiel- 
Table 1. Sites on São Miguel, Terceira, Graciosa and Flores from where collections of Chironomidae were obtained in 1997 and 1998. Latitude / longitude data in bold type are approximate. Site codes are used for species records in Table 2.

\begin{tabular}{|c|c|c|c|c|}
\hline Date & Code & Location & Latitude $\mathbf{N}$ & Longitude W \\
\hline \multicolumn{5}{|c|}{ São Miguel } \\
\hline $18-8-97$ & SM1 & Lagoa de Eguas, inlet stream & $37^{\circ} 49.6^{\prime}$ & $25^{\circ} 44.9^{\prime}$ \\
\hline $18-8-97$ & SM2 & Trough on road, north east of Cerrado das Freiras & $37^{\circ} 51.5^{\prime}$ & $25^{\circ} 46.6^{\prime}$ \\
\hline $23-9-98$ & SM3 & Small pond at tea factory & $37^{\circ} 49.1^{\prime}$ & $25^{\circ} 23.8^{\prime}$ \\
\hline $23-9-98$ & SM4a & Ornamental ponds at Community Centre, Terra Nostra & $37^{\circ} 46.3^{\prime}$ & $25^{\circ} 18.7^{\prime}$ \\
\hline $23-9-98$ & SM $4 b$ & Thermal pool in Terra Nostra Park & $37^{\circ} 46.3^{\prime}$ & $25^{\circ} 18.7^{\prime}$ \\
\hline $23-9-98$ & SM4c & Ornamental pond inside east gate of Terra Nostra Park & $37^{\circ} 46.3^{\prime}$ & $25^{\circ} 18.7^{\prime}$ \\
\hline $23-9-98$ & SM5 & Lagoa das Furnas, near fumeroles & $37^{\circ} 46.1^{\prime}$ & $25^{\circ} 19.9^{\prime}$ \\
\hline $24-9-98$ & SM6 & Ribeiro do Lameiro, south of road EN1-1a & $37^{\circ} 48.7^{\prime}$ & $25^{\circ} 28.1^{\prime}$ \\
\hline $24-9-98$ & SM7 & Ribeira dos Caldeiroes, waterfall south of road EN1-1a & $37^{\circ} 50.6^{\prime}$ & $25^{\circ} 15.9^{\prime}$ \\
\hline $24-9-98$ & SM8 & Trough at cross road, EN1-2a, south of Nordeste & $37^{\circ} 49.1^{\prime}$ & $25^{\circ} 08.9^{\prime}$ \\
\hline $24-9-98$ & SM9 & Un-named stream, south of road En1-2a & $37^{\circ} 47.8^{\prime}$ & $25^{\circ} 10.6^{\prime}$ \\
\hline $24-9-98$ & SM10 & Lay-by on tributary of Rba Quente, on EN2a & $37^{\circ} 44.9^{\prime}$ & $25^{\circ} 18.6^{\prime}$ \\
\hline $24-9-98$ & SM11 & Lagoa das Furnas, shoreline & $37^{\circ} 45.8^{\prime}$ & $25^{\circ} 19.7^{\prime}$ \\
\hline $24-9-98$ & SM12 & Lagoa das Furnas, pumice-strewn south east shore & $37^{\circ} 45.1^{\prime}$ & $25^{\circ} 19.7^{\prime}$ \\
\hline $25-9-98$ & SM13 & Pond at Universidade dos Açores, Ponta Delgada & $37^{\circ} 44.7^{\prime}$ & $25^{\circ} 39.9^{\prime}$ \\
\hline $23-9-98$ & $\mathrm{SMml}$ & Marine sample on rocky shore at Ponta Delgada & $37^{\circ} 44.4^{\prime}$ & $25^{\circ} 39.7^{\prime}$ \\
\hline $25-9-98$ & SMm2 & Marine sample at Praia do Populo, Ponta Delgada & $37^{\circ} 44.9^{\prime}$ & $25^{\circ} 37.4^{\prime}$ \\
\hline \multicolumn{5}{|c|}{ Terceira } \\
\hline $29-9-98$ & $\mathrm{~T} 1$ & Trough at Serrata & $38^{\circ} 45.1^{\prime}$ & $27^{\circ} 21.9^{\prime}$ \\
\hline $30-9-98$ & $\mathrm{~T} 2$ & Lagoa do Negro & $38^{\circ} 44.8^{\prime}$ & $27^{\circ} 16.1^{\prime}$ \\
\hline $30-9-98$ & $\mathrm{~T} 3$ & Trough near Pico de Cancela & $38^{\circ} 43.8^{\prime}$ & $27^{\circ} 16.7^{\prime}$ \\
\hline $30-9-98$ & $\mathrm{~T} 4$ & Lagoa da Falca - lake, stream, trough & $38^{\circ} 43.1^{\prime}$ & $27^{\circ} 17.4^{\prime}$ \\
\hline $30-9-98$ & T5 & Rba Urzal, bridge at Quatros Ribeiras & $38^{\circ} 47.1^{\prime}$ & $27^{\circ} 13.7^{\prime}$ \\
\hline $1-10-98$ & T6 & Lagoa do Junco & $38^{\circ} 42.6^{\prime}$ & $27^{\circ} 07.4^{\prime}$ \\
\hline $1-10-98$ & $\mathrm{~T} 7$ & Lagoa do Ginjal & $38^{\circ} 41.8^{\prime}$ & $27^{\circ} 09.5^{\prime}$ \\
\hline $1-10-98$ & $\mathrm{~T} 7 \mathrm{a}$ & Trough near L. do Ginjal & $38^{\circ} 41.5^{\prime}$ & $27^{\circ} 09.6^{\prime}$ \\
\hline $1-10-98$ & $\mathrm{~T} 8$ & Trough, Sra do Rosario, Caminha das Guerilhas & $38^{\circ} 41.0^{\prime}$ & $27^{\circ} 16.4^{\prime}$ \\
\hline $1-10-98$ & T9 & Trough, Ribera Brava X-road, Picos dos Padres & $38^{\circ} 41.7^{\prime}$ & $27^{\circ} 17.4^{\prime}$ \\
\hline $2-10-98$ & $\mathrm{~T} 10$ & Trough, Tereiro da Macela & $38^{\circ} 46.0^{\prime}$ & $27^{\circ} 15.0^{\prime}$ \\
\hline $2-10-98$ & $\mathrm{~T} 11$ & Tributary of Rba Urzal & $38^{\circ} 46.4^{\prime}$ & $27^{\circ} 13.7^{\prime}$ \\
\hline $2-10-98$ & $\mathrm{~T} 12$ & Trough $2 \mathrm{Km}$ south east of Ponta das Quatros Ribeiras & $38^{\circ} 47.1^{\prime}$ & $27^{\circ} 12.8^{\prime}$ \\
\hline $2-10-98$ & $\mathrm{~T} 13$ & Trough at Farroco, south of Ponta do Misterío & $38^{\circ} 47.5^{\prime}$ & $27^{\circ} 12.3^{\prime}$ \\
\hline $3-10-98$ & T14 & Trough near entrance to Foreleza de S. Joao Baptista & $38^{\circ} 39.2^{\prime}$ & $27^{\circ} 13.6^{\prime}$ \\
\hline $3-10-98$ & $\mathrm{~T} 15$ & Trough, Rua Jose Agostinho, Angra do Heroísmo & $38^{\circ} 39.4^{\prime}$ & $27^{\circ} 13.6^{\prime}$ \\
\hline $30-9-98$ & $\mathrm{Tml}$ & Marine sample from rock pools, Biscoitos & $38^{\circ} 48.1^{\prime}$ & $27^{\circ} 15.5^{\prime}$ \\
\hline $1-10-98$ & $\mathrm{Tm} 2$ & Marine-sample on shoreline at Baía de Vila Maria & $38^{\circ} 39.3^{\prime}$ & $27^{\circ} 15.5^{\prime}$ \\
\hline $2-10-98$ & $\mathrm{Tm} 3$ & Marine sample on shoreline at Praia da Vitória & $38^{\circ} 43.5^{\prime}$ & $27^{\circ} 03.6^{\prime}$ \\
\hline $2-10-98$ & $\operatorname{Tm} 4$ & Marine sample on shoreline at Quatro Riberas & $38^{\circ} 47.5^{\prime}$ & $27^{\circ} 13.8^{\prime}$ \\
\hline \multicolumn{5}{|c|}{ Graciosa } \\
\hline $26-9-98$ & G1 & Trough before Caldeira tunnel & $39^{\circ} 01.8^{\prime}$ & $27^{\circ} 59.0^{\prime}$ \\
\hline $26-9-98$ & G2 & Trough at Canada Longa & $39^{\circ} 02.4^{\prime}$ & $27^{\circ} 59.2^{\prime}$ \\
\hline $26-9-98$ & G3 & Troughs, inshore from Baia de Engrade & $39^{\circ} 01.5^{\prime}$ & $27^{\circ} 57.4^{\prime}$ \\
\hline $27-9-98$ & G4 & Trough near Pedreias & $39^{\circ} 02.7^{\prime}$ & $28^{\circ} 02.6^{\prime}$ \\
\hline $27-9-98$ & G5 & Bath in field, Caminho do Meio & $39^{\circ} 04.3^{\prime}$ & $28^{\circ} 01.9^{\prime}$ \\
\hline $27-9-98$ & G6 & Municipal trough, Canada do Brijes & $39^{\circ} 04.5^{\prime}$ & $28^{\circ} 03.9^{\prime}$ \\
\hline $27-9-98$ & G7 & Small reservoirs near Ribeirinha & $39^{\circ} 03.2^{\prime}$ & $28^{\circ} 02.6^{\prime}$ \\
\hline $27-9-98$ & G8 & Eutrophic pond near Caldeirinha & $39^{\circ} 02.6^{\prime}$ & $28^{\circ} 01.7^{\prime}$ \\
\hline $27-9-98$ & G9 & Trough near windfarm- west side of Serra Dormida & $39^{\circ} 02.2^{\prime}$ & $28^{\circ} 01.6^{\prime}$ \\
\hline $28-9-98$ & G10 & Concrete pool at Santa Cruz Cultural Centre & $39^{\circ} 05.2^{\prime}$ & $28^{\circ} 00.7^{\prime}$ \\
\hline $28-9-98$ & G11 & Deep well, Caminha de Igreja & $39^{\circ} 03.7^{\prime}$ & $28^{\circ} 01.2^{\prime}$ \\
\hline $28-9-98$ & G12 & Path to Furna do Enxofre & $39^{\circ} 01.4^{\prime}$ & $27^{\circ} 58.3^{\prime}$ \\
\hline $28-9-98$ & $\mathrm{Gm} 1$ & Marine rocky shore at Santa Cruz & $39^{\circ} 05.2^{\prime}$ & $28^{\circ} 00.4^{\prime}$ \\
\hline $28-9-98$ & $\mathrm{Gm} 2$ & Marine sample -harbour at Santa Cruz & $39^{\circ} 05.1^{\prime}$ & $28^{\circ} 00.2^{\prime}$ \\
\hline \multirow{2}{*}{\multicolumn{5}{|c|}{ Flores }} \\
\hline & & & & \\
\hline $13-8-97$ & $\mathrm{~F} 1$ & Shoreline of Lagoa Basa & $39^{\circ} 24.4^{\prime}$ & $31^{\circ} 13.2^{\prime}$ \\
\hline $13-8-97$ & $\mathrm{~F} 2$ & Cascata pool, Rba das Casas, Porto de Faja Grande & $39^{\circ} 27.5^{\prime}$ & $31^{\circ} 15.2^{\prime}$ \\
\hline $14-8-97$ & F3 & Tank in Parque Florestal, Fazendas de Santa Cruz & $39^{\circ} 27.7^{\prime}$ & $31^{\circ} 09.2^{\prime}$ \\
\hline
\end{tabular}


Table 2. Distribution of the 33 chironomid taxa identified from samples collected in 1997 and 1998 at sites (codes in Table 1) on São Miguel, Terceira, Graciosa and Flores. Site codes in bold type indicate new species records for the island. «Status» indicates new records for the Azores archipelago.

\begin{tabular}{|c|c|c|c|c|c|}
\hline Taxon & S. Miguel & Terceira & Graciosa & Flores & Status \\
\hline \multicolumn{6}{|l|}{ Subfamily Telmatogetoninae } \\
\hline Thalassomya frauenfeldi Schiner & & $\operatorname{Tm} 2$ & & & \\
\hline \multicolumn{6}{|l|}{ Subfamily Tanypodinae } \\
\hline Macropelopia nebulosa (Meigen) & & $\mathrm{T} 14$ & & & \\
\hline Procladius (Holotanypus) choreus (Meigen) & & $\mathbf{T} 2,3,7 \mathrm{~b}, 10,13$ & $\mathrm{G} 4,5,7,9,10$ & & New \\
\hline Paramerina sp (sp Griechenland Fittkau 1962) & & T5, T12 & & & New \\
\hline Zavrelimyia sp & SM6, 7 & T4 & & & New \\
\hline \multicolumn{6}{|l|}{ Subfamily Orthocladiinae } \\
\hline Camptocladius stercorarius (De Geer) & & $\mathrm{T} 2$ & & & \\
\hline Cardiocladius freyi Storå ? & SM2 & $\mathrm{T} 5$ & & $\mathrm{~F} 2$ & \\
\hline Cricotopus (Halocladius) varians (Stæger) & & & Gm1 & & \\
\hline Cricotopus (Isocladius) ornatus (Meigen) & & T9 & & & \\
\hline Cricotopus (Isocladius) sylvestris (Fabricius) & & $\mathrm{T} 1, \mathbf{7 ,}, 13$ & $\mathbf{G} 2,3,7,9,10$ & & \\
\hline Cricotopus sp & & & G6 & & \\
\hline Limnophyes minimus (Meigen) & & & & $\mathrm{F} 2$ & \\
\hline Metriocnemus fuscipes (Meigen) & & $\mathrm{T} 11$ & & & \\
\hline \multicolumn{6}{|l|}{ Metriocnemus (Inermipupa) } \\
\hline carmencitabertarum Langton \& Cobo & & T15 & & & New \\
\hline Orthocladius (Eudactylocladius) sp & SM7 & T5, 12 & & F2 & New \\
\hline Parametriocnemus stylatus (Kieffer) & & T5 & & $\mathrm{F} 2$ & \\
\hline Psectrocladius limbatellus (Holmgren) & & T9, 12, 13 & & & New \\
\hline Psectrocladius $\mathrm{sp}$ & & & & F1 & New \\
\hline Pseudorthocladius $\mathrm{sp}$ & SMm2 & & & & New \\
\hline Pseudosmittia brevifurcata (Edwards) & & & Gm2 & & \\
\hline $\begin{array}{l}\text { Rheocricotopus (Psilocricotopus) atripes } \\
\quad \text { (Kieffer) }\end{array}$ & SM6 & & & $\mathrm{F} 2$ & \\
\hline Smittia contingens (Walker) & SM6 & & & & New \\
\hline "Thalassosmittia" atlantica (Storå) & & $\operatorname{Tm} 1,23,4$ & Gm1, Gm3 & & \\
\hline Thienemanniella clavicornis (Kieffer) & & T5 & & & \\
\hline \multicolumn{6}{|l|}{ Subfamily Chironominae } \\
\hline Chironomus cingulatus Meigen & SM11, 12 & $\mathrm{~T} 2, \mathbf{3}, \mathbf{7 b}, \mathbf{1 0}, 12$ & G3, 4, 9, 11 & & New \\
\hline Chironomus riparius Meigen & $\mathrm{SM} 2,8$ & T9, 12, 15 & G9, 10 & F3 & \\
\hline Chironomus cf annularius (De Geer) & & & G10 & & New \\
\hline $\begin{array}{l}\text { Glyptotendipes (Phytotendipes.) barbipes } \\
\text { (Staeger) }\end{array}$ & SM13 & T3, 15 & $\mathrm{G} 2,4,6,7$ & & New \\
\hline Glyptotendipes $(P)$ pallens (Meigen) & & $\mathbf{T} 2$ & G3, 10 & & New \\
\hline $\begin{array}{l}\text { Polypedilum (Polypedilum) nubeculosum } \\
\text { (Meigen) }\end{array}$ & & $\mathrm{T} 8,10,12$ & & & \\
\hline Polypedilum (Polypedilum) nubifer (Skuse) & & $\mathrm{T} 3,9,13,14$ & G2,G7 & & New \\
\hline Micropsectra sp. (cf lindrothi Goetghebuer) & & T12 & & F1 & New \\
\hline Paratanytarsus grimmii (Schneider) & & T2, 9 & & & New \\
\hline Number of taxa recorded on each island & 9 & 24 & 12 & 8 & \\
\hline Number of taxa new to each island & 6 & 16 & 12 & 4 & \\
\hline
\end{tabular}

ding a wealth of taxonomic characters not available or used extensively in taxonomic resolutions by earlier workers. The collection and examination of pupal exuviae in this study has confirmed the presence of some previously recorded taxa, provided evidence of previously unrecorded taxa and also suggests that some former determinations may be inaccurate. A species list, incorporating the known distribution of Chironomidae on the eight islands studied during previous investigations and in the present study, is given in Table 3. This table includes species regarded as nomina dubia by Cobo et al. (2002) and by Ashe \& Cranston (1990), pending further taxonomic investigation and final resolution. The sixteen taxa that constitute new 
Table 3. Updated list of chironomid species-level taxa from São Miguel (SMi), Terceira (Ter), Graciosa (Gra), São Jorge (SJo), Pico (Pic), Faial (Fai), Flores (Flo) and Corvo (Cor). Previous / existing records are denoted «»», existing records confirmed in the present study are denoted «C», new records are denoted «N».

\begin{tabular}{|c|c|c|c|c|c|c|c|c|}
\hline & $\mathbf{S M i}$ & Ter & Gra & SJo & Pic & Fai & Flo & Cor \\
\hline \multicolumn{9}{|l|}{ Telmatogeninae } \\
\hline Thalassomya frauenfeldi Schiner & $P$ & $\mathrm{C}$ & & $P$ & $\mathrm{P}$ & $\mathbf{P}$ & $\mathbf{P}$ & $\mathrm{P}$ \\
\hline \multicolumn{9}{|l|}{ Tanypodinae } \\
\hline Macropelopia nebulosa (Meigen) & $\mathrm{P}$ & $\mathrm{C}$ & & $P$ & & & $P$ & \\
\hline Procladius (Holotanypus) choreus (Meigen) & & $\mathrm{N}$ & $\mathrm{N}$ & & & & & \\
\hline Paramerina pygmaea (van der Wulp) & $\mathrm{P}$ & $\mathrm{P}$ & & & & & & \\
\hline Paramerina sp. Griechenland (sensu Fittkau 1962) & & $\mathrm{N}$ & & & & & & \\
\hline Telmatopelopia nemorum (Goetghebuer) & $\mathrm{P}$ & $\mathrm{P}$ & & $\mathbf{P}$ & & & $\mathbf{P}$ & \\
\hline Zavrelimyia nubila (Meigen) & $P$ & & & $P$ & $\mathrm{P}$ & $\mathrm{P}$ & $P$ & \\
\hline Zavrelimyia sp (sensu Hughes \& Murray 2000) & $\mathrm{N}$ & $\mathrm{N}$ & & & & & & \\
\hline \multicolumn{9}{|l|}{ Diamesinae } \\
\hline Diamesa (Nesodiamesa) alata Storå & $\mathrm{P}$ & $P$ & & & & $P$ & & \\
\hline \multicolumn{9}{|l|}{ Orthocladiinae } \\
\hline Camptocladius stercorarius (De Geer) & $P$ & $\mathrm{C}$ & & $P$ & $P$ & $P$ & $P$ & \\
\hline Cardiocladius freyi Storå & $\mathrm{C}$ & $\mathrm{C}$ & & $\mathrm{P}$ & & & $\mathrm{C}$ & \\
\hline Chaetocladius melaleucus (Meigen) & $\mathrm{P}$ & $P$ & & & & & $\mathrm{P}$ & $P$ \\
\hline Cricotopus (Halocladius) sp & $\mathrm{P}$ & & & $\mathbf{P}$ & $\mathrm{P}$ & $\mathrm{P}$ & $P$ & \\
\hline Cricotopus (Halocladius) varians (Staeger) & & & $\mathrm{N}$ & $P$ & & $P$ & $P$ & \\
\hline Cricotopus (Isocladius) ornatus (Meigen) & $\mathrm{P}$ & $\mathrm{N}$ & & & & & & \\
\hline Cricotopus (Isocladius) sylvestris (Fabricius) & $P$ & $\mathrm{~N}$ & $\mathrm{~N}$ & & & & & \\
\hline Cricotopus sp (larva) & & & $\mathrm{N}$ & & & & & \\
\hline Limnophyes minimus (Meigen) & $P$ & $\mathrm{P}$ & & & $\mathrm{P}$ & $\mathbf{P}$ & $\mathrm{C}$ & \\
\hline Metriocnemus fuscipes (Meigen) & $P$ & $\mathrm{C}$ & & $\mathrm{P}$ & $\mathrm{P}$ & $P$ & $\mathrm{P}$ & \\
\hline \multicolumn{9}{|l|}{ Metriocnemus (Inermipupa) carmencitabertarum } \\
\hline Langton \& Cobo & & $\mathrm{N}$ & & & & & & \\
\hline Orthocladius rivularis (nomen dubium) & $\mathrm{P}$ & & & & & & $\mathrm{P}$ & \\
\hline Orthocladius (Eudactylocladius) sp & $\mathrm{N}$ & $\mathrm{N}$ & & & & & $\mathrm{N}$ & \\
\hline Parametriocnemus stylatus (Kieffer) & $\mathrm{P}$ & $\mathrm{C}$ & & & & $P$ & $\mathrm{C}$ & \\
\hline Psectrocladius insularis (nomen dubium) & $\mathrm{P}$ & $P$ & & $\mathbf{P}$ & & $\mathrm{P}$ & $\mathrm{P}$ & $P$ \\
\hline Psectrocladius limbatellus (Holmgren) & & $\mathrm{N}$ & & & & & & \\
\hline Psectrocladius sordidellus (Zetterstedt) & $\mathrm{P}$ & $\mathrm{P}$ & & & & & & \\
\hline Psectrocladius $s p$ & & & & & & & $\mathrm{~N}$ & \\
\hline Pseudosmittia azorica (Storå) (nomen dubium) & $\mathrm{P}$ & $\mathbf{P}$ & $P$ & $\mathbf{P}$ & $\mathbf{P}$ & $\mathrm{P}$ & $\mathrm{P}$ & $\mathrm{P}$ \\
\hline Pseudorthocladius sp & $\mathrm{N}$ & & & & & & & \\
\hline Pseudosmittia brevifurcata (Edwards) & & & $\mathrm{N}$ & $P$ & $\mathrm{P}$ & & & \\
\hline Rheocricotopus (Psilocricotopus) atripes (Kieffer) & $\mathrm{C}$ & $\mathrm{P}$ & & $P$ & & $\mathrm{P}$ & $\mathrm{C}$ & \\
\hline Smittia aterrima (Meigen) & $\mathrm{P}$ & & & & & & & \\
\hline Smittia contingens (Walker) & $\mathrm{N}$ & & & & & & & \\
\hline "Thalassosmittia" atlantica (Storå) & $\mathrm{P}$ & $\mathrm{C}$ & $\mathrm{N}$ & & $P$ & $P$ & $P$ & $\mathrm{P}$ \\
\hline Thienemannia gracei (Edwards) & & & & $\mathbf{P}$ & & & & \\
\hline Thienemanniella clavicornis (Kieffer) & $\mathrm{P}$ & $\mathrm{N}$ & & & & & & \\
\hline \multicolumn{9}{|l|}{ Chironominae } \\
\hline Chironomus venustus Staeger & $\mathrm{P}$ & $\mathrm{P}$ & $\mathrm{P}$ & $\mathrm{P}$ & & & & \\
\hline Chironomus cingulatus Meigen & $\mathrm{N}$ & $\mathrm{N}$ & $\mathrm{N}$ & & & & & \\
\hline Chironomus dorsalis Meigen & $\mathbf{P}$ & $\mathbf{P}$ & & $\mathrm{P}$ & & $\mathrm{P}$ & $P$ & \\
\hline Chironomus riparius Meigen & $\mathrm{C}$ & $\mathrm{N}$ & $\mathrm{N}$ & & $\mathrm{P}$ & $P$ & $\mathrm{~N}$ & \\
\hline Chironomus cf annularius & & & $\mathrm{N}$ & & & & & \\
\hline Glyptotendipes barbipes (Staeger) & $\mathrm{N}$ & $\mathrm{N}$ & $\mathrm{N}$ & & & & & \\
\hline Glyptotendipes pallens (Meigen) & & $\mathrm{N}$ & $\mathrm{N}$ & & & & & \\
\hline Polypedilum (Polypedilum) nubeculosum (Meigen) & $P$ & $\mathrm{C}$ & & & $\mathrm{P}$ & & & \\
\hline Polypedilum (Polypedilum) nubifer (Skuse) & & $\mathrm{N}$ & $\mathrm{N}$ & & & & & \\
\hline Micropsectra junci (Meigen) - syn subviridis & $P$ & $\mathrm{P}$ & & $\mathrm{P}$ & $P$ & $P$ & $P$ & $\mathrm{P}$ \\
\hline Micropsectra freyi Storå (nomen dubium) & & & & $\mathbf{P}$ & & & & \\
\hline Micropsectra cf lindrothi Goetghebuer & & $\mathrm{N}$ & & & & & $\mathrm{N}$ & \\
\hline Paratanytarsus grimmii (Schneider) & & $\mathrm{N}$ & & & & & & \\
\hline Tanytarsus $s p$ & $\mathrm{P}$ & & & & $\mathrm{P}$ & & $\mathrm{P}$ & $\mathrm{P}$ \\
\hline Total number of taxa from each island & 35 & 36 & 14 & 18 & 13 & 16 & 24 & 7 \\
\hline
\end{tabular}


records for the Azores, and the further records of species already known to occur in the Azores, extend considerably the knowledge base of chironomid distribution in the archipelago.

Some of the recently discovered taxa appear to have a restricted distribution on the islands from which samples were obtained. For example, Procladius choreus, Glyptotendipes pallens and Polypedilum nubifer were only obtained on the central group islands of Terceira and Graciosa while Glyptotendipes barbipes was found in these central islands and on the eastern island of São Miguel. In contrast, Cardiocladius freyi and the hygropetric Eudactylocladius sp. occur across the archipelago from São Miguel to Flores while species such as Smittia contingens and Paratanytarsus grimmii are thus far only known from São Miguel and Terceira respectively.

\section{Azorean chironomid species - area relationship}

Combining results from the present study with those of earlier investigations reveals differences in chironomid species richness ( $\alpha$ diversity) between the Azorean islands. MacArthur and Wilson (1967) demonstrated a linear relationship between the logarithm of species number and the logarithm of island area for discrete island groups within a geographic region. Da- ta from the present and past studies in the Azores provides the species-area relationship plot in Fig 2. Datapoints for Corvo, Faial, São Jorge and Pico, based only on records from earlier studies, fall below the regression line, in contrast to the recently investigated islands of Flores, Graciosa, Terceira and São Miguel. The low species number on the smaller, more remote, island of Corvo is not unexpected. The data points for Faial and São Jorge lie closer to predicted values but the point derived from the low species number on Pico would suggest that further collection effort would be likely to yield additional species records there.

\section{Comments on some records}

\section{Subfamily Tanypodinae}

Procladius choreus (Meigen) : The records of Procladius from Terceira and Graciosa are the first findings of the genus for the Archipelago. $P$. choreus has a widespread Palaearctic distribution and is also known from Madeira and the Canary Islands.

Paramerina pygmaea (van der Wulp), Paramerina sp. Griechenland : Freeman (1959) first recorded Pentaneura cingulata, now a synonym of $P$. pygmaea, from specimens collected on São Miguel. A possibility exists, however, that adults identified by Freeman

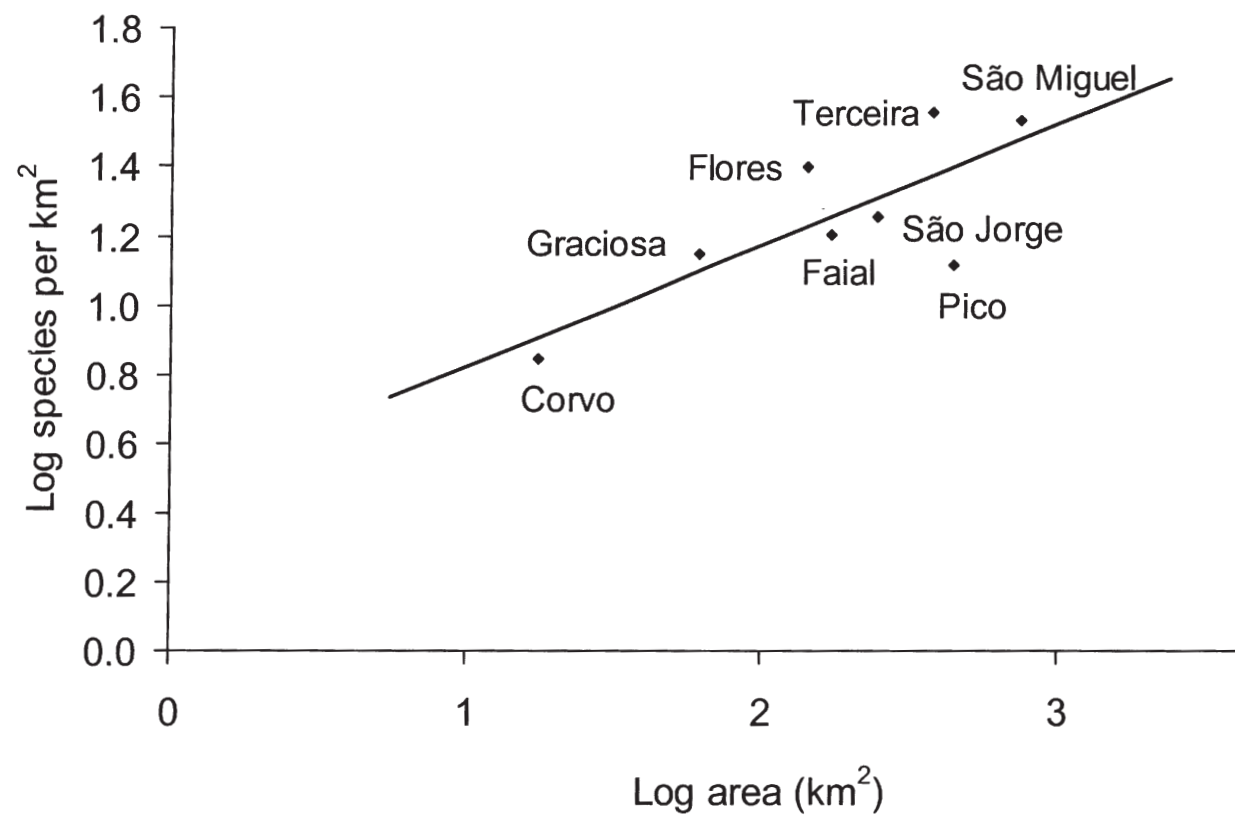

Fig. 2. Chironomid species area relationship for islands of the Azores Archipelago. 
belong to an undescribed species within Paramerina whose characteristic pupal exuviae, designated as $\mathrm{Pa}$ ramerina sp. Griechenland (Fittkau 1962), were collected on Terceira in this study. Pupal exuviae of this species have been found in a number of circum-Mediterranean countries (Langton 1991). It is known from the Iberian Peninsula and has also been recorded from Madeira (Hughes \& Murray 2000).

Telmatopelopia nemorum (Goetghebuer) : Storå (1945) provided the only known records of this species, as Ablabesmyia nemorum, from four of the Azorean islands. The species is now placed in Telmatopelopia Fittkau.

Zavrelimyia nubila (Meigen) and Zavrelimyia sp. : Stora (1945) recorded Ablabesmyia nubila, now in $\mathrm{Za}$ vrelimyia Fittkau, on São Miguel. As with $P$. pygmaea cited above, some doubt exists about the record of $Z$. nubila since pupal exuviae obtained on São Miguel and Terciera in this study differ from descriptions of Z. nubila in Fittkau (1962) and from key characters in Langton (1991). The Azorean exuviae are similar to those recorded from Madeira (Hughes \& Murray 2000) and described in Hughes \& Murray (2001). Associated adults of this species have yet to be discovered and described. It is likely that the records of the taxon «Ablabesmyia nubila» by Stora (1945) from the Azores, and of «Pentaneura nubila» by Freeman (1959) from Madeira, may both be assigned to this new taxon which may also occur on the Canary Islands. Armitage et al. (1995) provide a record of an undetermined species «Zavrelimyia nubila?» from Tenerife. More recently, material collected during 1999 in a survey of insects of the Caldera de Taburiente National Park, La Palma Island, coordinated through the Museo Nacional de Ciencias Naturales, Madrid, has also yielded adult males of an undescribed Zavrelimyia species (D. Murray, pers. com.).

\section{Subfamily Orthocladiinae}

Camptocladius stercorarius (De Geer) : This species, recorded on Terceira in the present study, was previously recorded as Smittia stercoraria by both Storå (1945) and Freeman (1959). Larvae of C. stercorarius characteristically live in animal dung. The species has a widespread Azorean distribution and also occurs in Madeira and the Canary Islands.

Cardiocladius freyi Stora : Adult males of Cardiocladius freyi were described by Storå (1936) from collections made on the Canary Islands of Gran Canaria and Tenerife in 1931. Later Stora (1945) gave additional records from the Azores (São Miguel, Terceira and Flores) and Madeira. C. freyi has not so far been recor- ded elsewhere, perhaps indicating an endemic Macaronesian distribution. The pupa of $C$. freyi, although known from studies on Madeira (Hughes \& Murray 2000), is thus far undescribed. However, exuviae collected during this study, also on São Miguel, Terceira and Flores, are similar in form to those collected in Madeira and are readily recognised by their smooth dorsal thoracic surface, in contrast to the highly tuberculate thorax in the other common European species, C. fuscus and C. capucinus.

Halocladius (Halocladius) varians (Staeger) : This marine coastal species, recorded on Graciosa in this study, was previously recorded from São Jorge and Flores as Cricotopus halophilus (Meigen) now considered as a synonym of Halocladius varians (Staeger) (Hirvenoja 1973).

Halocladius (H.) sp. : Stora (1945) recognised the marine species Cricotopus vitripennis Meigen from São Miguel, São Jorge, and Flores. According to Hirvenoja (1973) a large proportion of records cited in the early literature as $C$. vitripennis actually belong to $H$. (Halocladius) variabilis (Staeger). However, Hirvenoja noted that the Azores specimens identified by Stora differed from his concept of $H$. $(H$.) variabilis and suggested that the Azorean specimens might possibly represent a new species within Halocladius. Murray \& Hughes (2000) provided a brief diagnosis of another undescribed Halocladius species from Madeira. This, however, differs from the Azorean species.

Metriocnemus (Inermipupa) carmencitabertarum Langton \& Cobo : This species, recorded from a municipal trough in Angra do Heroismo, Terceira, is hitherto only known from the Iberian Peninsula (Soriano et al. 1997). Although its characteristic pupal stage was recognised from the River Zezere, Portugal and included in Langton (p. 82: 1991) as «Orthocladiinae gen.? sp.? Pe3», its description as a new species within the new subgenus Inermipupa was based on material collected in 1994 in Galicia, north-western Spain (Langton \& Cobo, 1997).

Orthocladius (Eudactylocladius) sp. : Exuviae of this characteristic taxon, obtained on São Miguel, Terceira and Flores, differ from known species. The presence of a posterior point band on tergite VIII separates the species from E. fuscimanus (Kieffer) but the presence of three equally strong anal macrosetae distinguishes it from Eudactylocladius olivaceus (Kieffer) and Eudactylocladius Pe2 in Langton (1991). A single adult male Eudactylocladius, collected from Rba. das Casas, Flores along with pupal exuviae, also differs from known species. The structure of the hypopygium bears a striking resemblance to Stora's (1945 - Fig 28) depiction of Or- 
thocladius rivularis. A strong possibility exists that the material identified as Eudactylocladius $\mathrm{sp}$ in this study may belong to $O$. rivularis. Resolution of this question must await critical examination of any available material of $O$. rivularis from previous collections.

Psectrocladius limbatellus (Holmgren), P. sordidellus (Zetterstedt), Psectrocladius sp. : The characteristic exuviae of $P$. limbatellus, collected on Terceira, represent the first record of this species from the Azores. A second species, $P$. sordidellus, was recorded by Storå (1945) under its synonym $P$. stratiotis. Previous records exist for a third species, $P$. sordidellus var insularis Storå, considered nomen dubium in Ashe \& Cranston (1990). During the present study a single pupal exuviae, differing from $P$. limbatellus and $P$. sordidellus, was obtained at Lagoa Basa on Flores presenting evidence of a third Psectrocladius taxon on the archipelago. It is not possible, however, to correlate this specimen with the doubtful taxon, $P$. sordidellus var insularis Stora.

Pseudorthocladius sp ? : The record of a single Pseudorthocladius adult male over rocks on the marine shoreline at Ponta Delgada on São Miguel represents the first record of this genus from the Azores. Collection and further examination of additional material is necessary to bring the determination to species.

«Thalassosmittia» atlantica (Storå) : This species was originally described from the Canary Islands as $E u$ kiefferiella atlantica by Stora (1936). It is also known from Madeira and may be regarded a characteristic marine (endemic?) species on rocky coastal regions of Macaronesian islands. It was first recorded from the Azores by Storå (1945) and later by Freeman (1959). In this study numerous adult (male and female) imagines were obtained from marine coastal sites on Terceira and Graciosa. While it is a valid species, its generic placement is currently unstable. Stora (1936) was uncertain about its generic placement in his original description and while some characters suggested placement in Smittia, based on defining features in wing venation, he assigned it to Eukiefferiella. Freeman (1959) also considered this species within Eukiefferiella, but as a subgenus of Nanocladius. Armitage (1986) provided modern descriptions of the adult male, based on his examination of original type specimens and new material collected on Tenerife, but also suggested some uncertainty about its generic placement in Eukiefferiella. Subsequently, having found and described larvae, pupae and adult females, Armitage and Tuiskunen (1988) transferred the species to the genus Thalassosmittia. However, Wang and Sæther (1993) excluded T. atlantica in their work on the Palaearctic species of
Thalassosmittia and more recently Sæther et al. (2000) treated «T. atlantica» as a separate taxon in the key to genera of the known Palaearctic Chironomidae. Further detailed examination of all life history stages is desirable and while it is apparent that the species is related to Thalassosmittia, it may prove necessary to erect a new genus to accommodate the species and resolve this predicament.

\section{Subfamily Chironominae}

Chironomus cingulatus Meigen; $C$. cingulatus var. venustus Staeger; C. dorsalis Meigen; C. riparius Meigen; $\boldsymbol{C}$. cf annularius (De Geer) : Three species of Chironomus are cited in previous studies. The species variety $C$. cingulatus var. venustus, recognised by Storå (1945) is now considered a valid species, $C$. venustus (Staeger). In the present study $C$. venustus was not found but exuviae determined as $C$. cingulatus were recorded from São Miguel, Terceira and Graciosa. C. dorsalis was reported by Stora (1945) but not found either by Freeman (1959) or in this study. Under the name $C$. thummi, Freeman (1959) reported $C$. riparius from São Miguel, Faial and Pico and in this study numerous exuviae were collected from the Terra Nostra thermal pools on São Miguel. Among the collections from an artificial pool at the Santa Cruz Community Centre, exuviae of $C$. riparius were obtained together with a second species tentatively identified as $C$. cf $a n$ nularius (De Geer).

Glyptotendipes (Phytotendipes) barbipes (Staeger), G. (P.) pallens (Meigen) : These are the first records of the genus Glyptotendipes from the Azores. The characteristic pupal exuviae of both species were obtained in mutually exclusive sites on Terceira and Graciosa. G. barbipes only was recorded on São Miguel. G. pallens is also known from Madeira (Hughes \& Murray 2000).

Polypedilum (Polypedilum) nubifer (Skuse) : P. nubifer, obtained on Terceira and Graciosa, has not been found previously in the Azores. Becker (1908) described $P$. lene, which was synonymised with $P$. nubifer by Cranston \& Armitage (1988), from the Canary Islands. The species was reported from Madeira by Hughes \& Murray (2000) and has an almost worldwide distribution.

Micropsectra freyi Stora, M. junci (Meigen), Micropsectra sp. (cf lindrothi Goetghebuer) : Micropsectra freyi was previously recorded from São Jorge by Storå (1936). It was not found in Azores material examined by Freeman (1959) but was present in contemporaneous collections examined from Madeira. The species was considered nomen dubium in Ashe \& Cranston (1990). M. junci (Meigen) was found in both previous 
investigations on the Azores as M. subviridis (Goetghebuer) but it was not found in the present study. Collections from a roadside trough near Pico de Padres on Terceira (site T9) and from Lagoa Basa on Flores (site F1) contained exuviae which do not fully key out to species in Langton (1991) and are cited here as $\mathrm{Mi}$ cropsectra sp. (cf lindrothi Goetghebuer). Similar exuviae are present in collections from ongoing studies on Madeira (personal observation) and a possibility remains that these may represent the immatures of $M$. freyi or another, undescribed, species.

Paratanytarsus grimmii (Schneider) and Tanytarsus sp : This record of $P$. grimmii constitutes the first record of the genus from the Azores. $P$. grimmii is a parthenogenetic species with a seemingly world-wide distribution (Langton et al. 1988). Apart from its natural occurrence in shallow stagnant waters, it is also a common nuisance species in water distribution systems and frequently occurs in tap water. A possibility exists that the citation by Stora (1945) of records of females only of a green Tanytarsus species from São Miguel, Pico, Flores and Corvo may also relate to $P$. grimmii since Stora drew particular attention to the fact that only females of the small «Tanytarsus» species were obtained from larval rearings - («die Züchtung ergab nur Weibchen»-Storå, 1945, p 32). None of the collections in the present study contained representatives of the genus Tanytarsus.

\section{Discussion}

Forty nine species-level taxa are now recorded for the Azores archipelago but the number of species known from individual islands varies between 7 on Corvo and 36 on Terceira. These values are low in comparison with other Macaronesian islands, e.g. Madeira has 61 known species-level taxa (Hughes et al. 1998, Murray \& Hughes 2000, Hughes \& Murray 2000) while Tenerife, Canary Islands has 59 known species-level taxa (Armitage et al. 1995). The Macaronesian chironomid fauna is noticeably depauperate in comparison with the 147 species known from the Mediterranean island of Corsica, a mere $80 \mathrm{~km}$ from Italy (Laville \& Langton 2002) and the greater distance of Macaronesian islands from continental landmasses, from where colonisation most likely occurred, may be a factor in this paucity. However, comparison of the number of species on different island landmasses may be misleading for islands of different size. According to Hengeveld et al. (1995) simple rescaling of area (A) using $1 / 4$ power of area $\left(\mathrm{A}^{1 / 4}\right)$ is a useful «rule of thumb» that facilitates comparison of species richness in islands of different size. Rescaling of the species area relationship (number of species divided by $\mathrm{A}^{1 / 4}$ ) provides area-adjusted values (AAV) that allow more favourable comparison. Thus, AAVs for individual Azorean islands vary from 8.1 on Terceira (36 species) to 3.4 on Corvo ( 7 species) with intermediate values of 6.5 on São Miguel (35 species), 5.0 on Graciosa (14 species), 4.6 on São Jorge (18 species) and 4.4 on Faial (16 species). The 24 species known from Flores give an AAV of 6.9, more than twice that of Pico which is almost three times larger in area but which has a low AAV of 2.8 from its 13 known species.

In relation to other Macaronesian islands the AAV of 8.7 for Tenerife (59 species) is more or less comparable with Terceira whereas the AAV of 11.4 for Madeira (61 species) is noticeably higher. The relative poverty of the chironomid fauna of the Macaronesian islands is again evident when compared with Corsica (AAV 15.2 for 147 species-level taxa) but the comparison is more marked compared to the larger, more northern-latitude, temperate Atlantic islands of Great Britain (578 species, Chandler 1998) and Ireland (445 species, Murray \& Murray 2003) with AAVs of 26.4 and 26.1 respectively. These relatively high values reflect the closer proximity of these islands to the Palaearctic European landmass, their broader range of favourable habitats and the intensity of collection and publication of records. In contrast, Iceland, even more northerly in latitude and which is also well investigated, has 77 species (Hrafnsdottir et al. 2000, Murray 1999) yielding a low AAV of 4.3. Although abundant in surface waters and potentially habitat-rich, Iceland's harsh climate and isolation could account for its low species richness.

Faunal composition on oceanic islands is determined not only by past dispersal patterns but also by previous opportunities for colonisation and current potential for survival. Environmental variables offered by landscape heterogeneity, landmass area and altitudinal gradient play a major role, but for a taxon such as the Chironomidae the availability of aquatic habitats is a fundamental necessity. The scarcity of natural exposed surface waters on some Azorean islands has most likely influenced chironomid colonisation and survival opportunities and may account for the low species richness observed. However, information on island faunal composition is also dependent on intensity of collection. It is reasonable to expect that further collecting effort for Chironomidae in the Azores will yield additional species records for the Archipelago and may ultimately yield information that could alter the apparent distribution patterns observed in this brief study. 


\section{References}

Armitage P.D. 1986. - A redescription of Eukiefferiella atlantica Stora (Chironomidae, Diptera) based on type material and recently collected specimens from Tenerife, Canary Islands. Aquat. Insects, 8, 105-109.

Armitage P.D. \& Tuiskunen J. 1988. - Thalassosmittia atlantica (Storå) comb. nov. Description of adult female and immature stages from Tenerife, Canary Islands (Diptera, Chironomidae). Spixiana, Suppl., 14, 25-28.

Armitage P.D., Blackburn J.H., Nilsson A.N. \& Malmqvist B. 1995. - Chironomidae in freshwater habitats in Tenerife, Canary Islands. Pages 379-388 in Chironomidae - from genes to ecosystems. Cranston P.S. (ed). CSIRO, Canberra.

Ashe P. \& Cranston P.S. 1990. — Family Chironomidae. Pages 113499 in Catalogue of Palaearctic Diptera. Volume 2, PsychodidaeChironomidae. Soós A. \& Papp L. (eds). Elsevier, Amsterdam / Akadémiai Kiadó. Budapest.

Becker T. 1908. — Dipteren der Inseln Madeira. Mitt. zool. Mus. Berlin, 4, 1-180.

Borges P.A.V. \& Viera V. 1994. — The Entomological Bibliography of the Azores, II. The Taxa. Bol. Mus. Mun. Funchal, 46/251, 5-75.

Chandler P.J. 1998. — Checklists of insects of the British Isles (New Series). Part 1: Diptera - incorporating a list of Irish Diptera. Handbk. Ident. Br. Insects, 12 (2). Royal Entomological Society, London, $234 \mathrm{pp}$.

Cobo F., Soriano O. \& Gonzalez A.M. 2002. - Inventario do los Quironomidos (Diptera: Chironomidae ) de Portugal. Nov. Act. cient. Compostelana (Bioloxia), 11, 225-248.

Cranston P.S. \& Armitage P.D. 1988. - The Canary Islands Chironomidae described by T. Becker and by Santos Abreu. Deutsche ent. Zeit., N. F. 35, 341-354.

Fittkau E.J. 1962. — Die Tanypodinae. (Diptera : Chironomidae) Die Tribus Tanypodini, Macropelopiini, und Pentaneurini. Abhandlung zur Larvalsystematik der Insekten, 6. Akademie Verlag, Berlin, $453 \mathrm{pp}$.

Freeman P. 1959. - Chironomidae (Diptera, Nematocera) from the Azores and Madeira. Bol. Mus. Mun. Funchal, 12/29, 5-15.

Hengeveld R, Edwards P.J. \& Duffield S.J. 1995. — Biodiversity from an ecological perspective. Pages 88-106 in Global Biodiversity Assessment, Heywood V.H. (ed). United Nations Environment Programme, Cambridge University Press.

Hirvenoja M. 1973. - Revision der gattung Cricotopus van der Wulp und ihrer Verwandten (Diptera, Chironomidae). Ann. Zool. Fenn., 10, 1-36.

Hrafnsdottir T., Olafsson E. \& Olafsson J.E. 2000. — Occurrence and distribution of Chironomidae in Iceland. Pages 517-523 in Late $20^{\text {th }}$ Century Research on Chironomidae, Hoffrichter, O. (ed). Shaker Verlag, Aachen.

Hughes S.J. \& Murray D.A. 2000. - New records of Chironomidae (Diptera) from Madeira, five genera and sixteen species new to Macaronesia. Pages 525-234 in Late 20 ${ }^{\text {th }}$ Century Research on Chironomidae. Hoffrichter, O. (ed). Shaker Verlag, Aachen.

Hughes S.J. \& Murray D.A. 2001. - The pupa of Zavrelimyia sp. (Diptera; Chironomidae) from Madeira. Arquipélago -Life and Marine Sciences, Suppl. 2/B: 33-37.

Hughes S.J., Furse M.T., Blackburn J.H. \& Langton P.H. 1998. Checklist of Madeiran Freshwater Macroinvertebrates. Bol. Mus. Mun. Funchal, 50/284, 5-41.

Kehlmaier C. 1998. - Checklist of Diptera from the Azores. Bol. Mus. Mun. Funchal, 50/287, 71-90.
Laville H \& Langton P. 2002. - The lotic Chironomidae (Diptera) of Corsica (France). Ann. Limnol. - Int. J. Lim., 38, 53-64.

Langton P.H. 1991. - A key to the pupal exuviae of west Palaearctic Chironomidae. Privately Published, 344 p.

Langton P.H. \& Cobo F. 1997. - Metriocnemus (Inermipupa) carmencitabertarum subgen. n., sp. n. (Diptera: Chironomidae) from Spain and Portugal. Ent. Gaz., 48, 263-271.

Langton P.H., Cranston, P.S. \& Armitage P. 1988. — The parthenogenetic midge of water supply systems Paratanytarsus grimmi (Schneider) (Diptera: Chironomidae). Bull. ent Res., 78, 317-328.

MacArthur R.H. \& Wilson E.O. 1967. — The Theory of Island Biogeography. Princeton University Press, Princeton, NJ, USA. $302 \mathrm{p}$.

Murray D.A. 1999. - Two marine coastal-dwelling Chironomidae (Diptera) new to the fauna of Iceland: Telmatogeton japonicus Tokunaga (Telmatogetoninae) and Clunio marinus Haliday (Orthocladiinae). Bull. Ir. biogeog. Soc., 23, 89-91.

Murray D.A. \& Murray W.A. 2003. - A reassessment of Chironomidae (Diptera) of Clare Island, Co Mayo, Ireland, with first records of Acamptocladius reissi Cranston \& Sæther and Limnophyes angelicae Sæther (Orthocladiinae) for the Irish faunal checklist. Bull. Ir. biogeog. Soc., 27, 255-269.

Murray D.A. \& Hughes S. 2000. - New records of Marine Chironomidae (Diptera) from Madeira. Pages 575-588 in Late 20 th Century Research on Chironomidae. Hoffrichter, O. (ed). Shaker Verlag, Achen.

Sæther O.A., Ashe P. \& Murray D.A. 2000 - Family Chironomidae. Pages 113-334 in Contributions to a Manual of Palaearctic Diptera (with special reference to the flies of economic importance) Appendix 6. Papp L. \& Darvas B. (eds). Science Herald, Budapest.

Soriano O., Cobo F., Rieradevall M. \& Prat N. 1997. — Lista faunistica y bibliográfica de los quironómidos (Diptera, Chironomidae) de la Península Ibérica e Islas Baleares. Pages 1-210 in Lista de la Flora y Fauna de las Aguas Continentenales de la Peninsula Iberica. García-Avilés J. \& Rico E. (eds). Asociacion Española de Limnologia, Madrid.

Storå R. 1936. - Chironomidae. Pages 21-30 in Frey, R., Die Dipterenfauna der Kanarischen Inseln und ihre Probleme. Soc. scien. fenn. Comment. Biol., 6.

Storå R. 1945. - Chironomidae. Pages 22-32 in Frey, R. Tiergeographische Studien über die Dipterenfauna der Azoren. I Verzeichnes der bisher von der Azoren bekannten Dipteren. Soc. scien. fenn. Comment. Biol., 10.

Viera V. \& Borges P.A.V. 1993. - The Entomological Bibliography of the Azores. I. Thematic: General (mainly Biogeography), Applied Entomology, Ecology and Biospeleology. Bol. Mus. Mun. Funchal., 45/245, 5-28.

Wang X. \& Sæther O.A. 1993. - A new species of the 'marine' genus Thalassosmittia Strenzke \& Remmert from Xizang (Tibet), China (Diptera: Chironomidae). Ent. scand., 24, 211-214.

Wiederholm T. 1983. — (ed). Chironomidae of the Holarctic region. Keys and diagnoses. Part 1. Larvae. Ent. scand. Suppl., 19, 457 pp.

Wiederholm T. 1986. - (ed). Chironomidae of the Holarctic region. Keys and diagnoses. Part 2. Pupae. Ent. scand. Suppl., 28, 482 pp. Wiederholm T. 1989. - (ed). Chironomidae of the Holarctic region. - Keys and diagnoses. Part 3. Adult males. Ent. scand. Suppl., 34, 532 pp. 